\title{
THE SOURCES OF KHOREZM: ABOUT KARAKALPAK INDIVIDUALS IN THE CIVIL SERVICE OF KHIVA KHANS
}

\author{
Dosmaganbetov Sariboy \\ Nukus State Pedagogical Institute named after Ajiniyaz
}

Article DOI: $\underline{\text { https://doi.org/10.36713/epra9057 }}$

DOI No: 10.36713/epra9057

\begin{abstract}
The article describes in new scientific research the external and internal services of the Karakalpak hero-centurion Taylak, who served in the state in the first quarter of the XIX century during the reign of Khiva khan Muhammad Rahimkhan I (1806-1825).

KEYWORDS: Khiva, Historiography, Munis, Ogahi, "Firdavsi-il-iqbol" - "Garden of Happiness", Berdakh, Shajara (Family tree), Karakalpak individuals, Taylak - a brave centurion. Aris "Fourteen seeds", "Sheriyshi" seed. "Five castles".
\end{abstract}

\section{INTRODUCTION}

The historical figures of the Aral Sea region are an example (algorithm) for future generations about the role of heroes in history, and the works of historians are preserved as a social memoir, a revelation of the past, a historical annals. Territorial historical figures of the last century, Karakalpak guards to Khiva khan, reliable bases: The names of Taylak Batir, Tolagan Batir and Amanbay Batir in the historical poem "Shajara"(Family tree) by the great poet and historian of the Karakalpak people Berdakh (real name - Berdimurat Kargabay ugli 1827-1900), Khorezm historians mention it in the historical works of Munis (real name Shermuhamed Avaz biy ugli-Khorezmi. 1778-1829) and Ogahi(real name Muhammad Rizo Erniyozbek ugli. 18091874).

\section{METHODOLOGY}

Munis and Ogahi told in their works about Kuwandarya along the Sirdarya, around the Eastern Red Sands (Qizil kum), history, cultural and social life of the Karakalpak, Kazakh people, about historical events with the relations of Bukhara emirate during the reign of Khiva khan Muhammad Rahimkhan I, around the Eastern Aral Sea, Kishik Juz khans (khan of little tribe) along the Sir Darya, in the northern land "Aral-Qungirot".

In the work "Firdavs ul-ikbal" (The Garden of Happiness) on the Middle Ages of Central Asia is: 1) from the earliest period of Khorezm history to 1825 ;
2) It is a unique source in the coverage of the history of the Khiva khanate in the XVII-XIX centuries.

"Firdavs ul-ikbal" consists of an introduction, five main chapters and a conclusion. In chapters IV$\mathrm{V}$, the birth of Eltuzarkhan, the period of his reign, from the reign of Muhammad Rahimkhan, it is about events that took place before the work was completed. The titles of the chapters of the work also indicate that it contains a lot of valuable information about the history of the Turkic peoples. P. P. Ivanov called the work of Ogahi and Munis "The main source on the history of the Khiva khanate in the XVIII-XIX centuries."

\section{RESULTS AND DISCUSSIONS}

Ethnological view of the past: It is known from history that the Aral Sea Karakalpaks were formed from two main tribal associations - two Aris: "Qungirot" and "Fourteen" Big Seed. The "Aral Qungirot", founded 650 years ago by the "Qungirot Sufis" dynasty, became an independent khanate, striving for self-government and a life full of struggles, had fought wars for Independence, Freedom, Liberty. During the reign of Abulgazi Bahodirkhan (1643-1663) 374 years ago, it was transition from a nomadic lifestyle to a sedentary life of the members of Aris "Fourteen Seeds", the lower reaches of the Amu Darya and around the South Aral Sea. The representatives of the "Qitay" - a large tribe, as a part of the members of the Aris "Fourteen Seeds" tribe, were very influential. "Qitay" - a large tribe, twelve tribes (Bessari, Beksiyik; Qazayakli, 
Qaishili; Anna, Quin; Ayteke, Sheriyshi, Manjiuli, Bokliktay; Qirq; Aralbay) united to a strong union, the "Qitay-Sheriwshi" symbiosis has existed at different times and in different changes.

Sheriwshi-micro ethnos, if at one time there were a couple of "Anna - sheriwshi", at the same time in the symbiosis of "Ayteke-sheriwshi". They fought valiantly against their internal and external enemies in the areas where they had lived for centuries. Sheriwshi tribe was ruled by aksakals, warriors, and centurions. The chief of the Sheriwshi tribe had 62 (or 72) cavalry, who were in the military service of the Khiva khan and the Inaks. Sheriwshi Taylak Batir had a military unit with 100 (hundred) cavalry. They took part in various military campaigns, on the orders and instructions of the Khiva khan and his henchmen, went to neighboring countries and brought goods in the net.

Historical look at the past: At the end of the XVIII century - the first quarter of the XIX century, great events took place in the historical destiny of the peoples living around the Aral Sea and the Khorezm oasis. Qungirot-independent region, located near the South Aral Sea, was the administration to Khojamurat Bai and Turamurat Biy-Sufi, Jaksilik Biy to Khojayli region, Shonkarabiy ruled Aydos Biy, Aymurza Biy, Yangi Darya and Quwan along the rivers Nurtay biy, Orinbay biy and Maman biy; Kegeyli-Arna. Authoritative representatives of social and Muslim conditions in the northern land, great scholars: Hazrat Murat Sheikh Aziz Baba, Mulla Imam Muhammad Eshan united the people and showed devotion in spiritual and enlightenment education. At the end of the XVIII century and the first quarter of the XIX century, political and social life in Khorezm region was unstable. The throne of the Khiva khan was occupied by representatives of Tora dynasty "Oq suyak" (White Bone), brought from the desert, reign the country, inaks ruled the internal and external politics.

"Bes kala" (Five fortresses) of Khorezm did not unite, they were in neutrality, in a state of aggression. The emirs of Bukhara often sent their military forces to the lands of Khojayli, Mangit, Kipchak, and Old Urgench in the lower reaches of the Amu Darya, destroying the people. It is known from history that in 1779 Janmurat inak from Bukhara crossed the Amu Darya and besieged the city of Khojayli for seventeen days and nights. At the beginning of the 19th century, the Khiva khanate ceased to be ruled by the Inaks and was replaced by the Khanate. Thus, the dynasty of the Khiva qungirots took the throne of Khiva khanate and Eltuzar became (1804-1806) a khan. After the death of Eltuzar khan, his brother Muhammad Rahimkhan I (1806-1825) ascended the throne. In 20 years, he set the task of conquering and subjugating the Northern Land, reclaiming the old trade caravan routes, and paying taxes to the nomadic peoples. Khan of Khiva Muhammad Rahim I, in his internal and external policy, in military campaigns, relied heavily on the Karakalpak heroes and centurions along the Yangidarya, and "Oq Jagis" (names of the rivers).

In the annals of historian Ogahi: Urinbay Biy's son Davlatnazar and the representative of old "Qitay" tribe Taylak Batir (Hero) was in the service of the Khiva hunting organizer with an army of 100 (one hundred) cavalry. They collect taxes and wealth from the livestock and settlers of the Northern Land, protect the roadsides, carry out territorial control from the Yangidarya to the Amu Darya, from the town of Shurcha to the right bank of the river and to Khojayli served to pass through the "Water + Blood" channel.

Remembering the past. In the time of Abulgazi, from the city of "Mazda + qan" to the land of Hokim ota (territory of Moynak district) there were barley, wheat and millet fields. Two hundred years later, due to the ecological situation in the Aral Sea region and the military action of the invasion, the yield of grain and legumes was low, and the country was not prosperous. For this reason, the khanate collected grain and taxes through the use of military force. Taylak and Karabas Batir (Heroes) in the service of the khan, each with an army of 40-50 cavalry, took part in the collection of taxes from the common people. They forcibly took grain from farmers and foragers in the Amu Darya oasis and enslaved them in Khiva. Aydos biy, Kadirbergen biy, Kushbergen biy, Chigim biy and other centurions who united khanate and Karakalpak armies, were against Turamurat Sufi, the ruler of the "AralKungirot" in the northern land. Karakalpak soldiers and cavalry took part in the military campaigns of the khanate of Kuwan Darya and Sir Darya rivers.

A look at the annals of the palace historian Ogahi: Along the Lower Sir Darya, in the Kuwan Darya, in the Eastern Kizil Kum (Red Sand), the territory of the Kichik Juz (Little tribe) (Kichik Juzthree large tribal associations (boyuli, alimuli, jetiuru) (16th century)) includes the lands from the Ural and Tobol rivers to the lower reaches of the Sir Darya. It is bordered by the Central Asian states and the Kazakh and Karakalpak lands in the south, the Caspian Sea in the west, and Astrakhan, Saratov, and Orenburg provinces in the north, local population lived a nomadic lifestyle. Bektemir Ahun came to them with the participation of a thousand Kazakhs, a thousand Karakalpaks with the participation of Qirq Biy (Fourty elders), Traditionally elevating Aringazi to the "White Felt and elected him "Khan", he showed kingdom and blessings, respect and honor. Along the Lower Sir Darya, the news about Aringazi tora-sultan was "khan" to the tribe of the Kichik Juz (Little tribe) (Tabin, Tama, Teley, Kerderi, Kerey, Jagalbayli, Ramadan) reached Khiva. After this 
news, the khan sent his Karakalpak envoys emissaries: centurion Omon, centurion Taylak and Otaniyaz Batir along the Sir Darya. Among those who went to the Sirdarya, bad news reached the khan that Taylak batir had been captured and taken prisoner by Aringazi khan.

Archive sources: According to Orenburg province, which controlled the eastern borders (Orenburg province - the administrative unit of the Russian Empire 15.03.1744-14.05.1928): in 1819 in November in the cattle village of Kichik Juz (Little tribe) Taylak Batir, Amanbay Batir and Otaniyaz Batir were guests for three days.

Taylak Batir told the cattle elders along the Sir Darya about the order of the Khiva khan. According to the khan's order: the cattle of Kichik Juz (Horde) had to give 7700 (seven thousand seven hundred) sheep, including to Sirdarya region, the last khan of Kichik Juz Shergazi (Kayipov) the khan's son Jangazi Tora was a "khan" and was recognized by the whole population. Kichik Juz (Little tribe) Kazakh elders and Aringazi sultan "khan" consulted together, stopped the Karakalpak brokers-ambassadors, and then handed them over to the Orenburg authorities. But the khan's ambassadors - the "emissaries" centurion Oman and Otaniyaz batir (hero) found the right solution to this situation and escaped. Centurion Taylak Tolebay was quickly captured by the "internal gendarmerie", tied to a horse-drawn carriage and taken to Orenburg, and imprisoned in "Buzuluk" prison. Whenever there were any disputes or complaints between the cities of Khiva and Orenburg in Buzuluk prison, there was no reason to detain Khorezm traders and mullahs from Ulug Dala (Great Valley) Kazakhs imprisoned without any reason. Centurion Taylak Batir (Hero) spent 2 (two) years in Buzuluk prison, where he suffered from many hardships and prison conditions. (Buzuluk was founded in 1552 on the river Buzuluk. Now it is a city in Orenburg region of the Russian Federation). On December 16, 1821, the administration of Buzuluk prison handed over Taylak Batir to the owner of a caravan from Khiva and returned him to his homeland. From then, on the life of the captain Taylak was forgotten from the "historical scene", from the historical annals, and then from the memory of one or two generations.

In the annals of historian Agahi: In 1820, on the Sir Darya River, in the Aringazi nation there was an oral report sent by the khan, that the centurion Taylak had been captured in Orenburg. This created an excuse and reason for the next military campaigns of the "muonids", that is, a group of people in the spirit of hostility to the policy of the khan, contrary to their own pressure. "High esteemed Shahanshah" - is the khan of Khiva, for the second time led a new war against Dashti Kipchak, the people of Aringazi. Cavalry of Khiva khan crossed the Amu Darya, near the Baday tugai (Baday forest), and spent the night in the "Kizil kum" (Red Sand) desert, "the bright day in the dark," and theft the livestock on the banks of the "Oq Jagis," and then across the New River on the sand "Shur + kok" they reached Kornay, Mashorol, over the domed courtyard of Khojabergen, Nurum sultan's Horde. There, Aringazi's mother, wife and daughters were taken prisoner. In 12 (twelve) days, the military of the Khiva khan accumulated wealth and property that did not fit in the ledger. Jangazi Tora, who was near the Khiva khan, came to introduce himself to the cattle along Sir Darya and to recognize him as a khan. Jangazi Tora - "Khan" presented a variety of "nine + nine" hats, coats and gold shapans, expensive clothes to Kazakh elders, aksakals along the Sir, who won the hearts of many and demonstrated a pattern of compassion.

It was forgotten about the brave son of "Qitay" from the Great Tribe (Sheriwshi Little tribe) centurion Taylak, who left on a special mission of the Khan and was held captive for 2 years in a country far from his homeland. No one searched, no one was questioned...? ! This was a bitter historical fact.

History lessons: In the first quarter of the XIX century, during the reign of Khiva khan Muhammad Rahimkhan I, the Karakalpak Paternities, Centurions, Elders and Heroes took part in the internal and external policy of the khanate. They held positions in the interests of their tribal members. Centurion Tolagan and centurion Turabek from Karakalpaks took part in the khan's military campaigns in the neighboring lands with "cavalry". They went to the "Vordan" territory of the Bukhara emirate and drove away 300 (three hundred) camels of local cattle. Leading the Karakalpak cavalry: Qungirot, from the Qiyat tribe - Asenbay biy, Molla Qoroz biy, Qosbergen biy, Qadirberdi biy, Erejep biy, Aymurza biy, from the Mangit tribe representatives of Molla Davlatnazar biy, Shahniyaz biy, Keneges large tribes, "Omir" small tribe Shonkara biy ogli Kabul biy and Chagal mahram chief and a few hundred centurions appeared "new", the former centurions were forgotten, and the chariot of history, the lesson of history, continued to move forward.

\section{CONCLUSION}

At the end of the XVIII century - the first quarter of the XIX century in the historical destiny and historical figures of the Karakalpak people, great events in the social life, tragic wars were posted in the historical sources and archival documents. It is clear that the fate of our ancestors of that time, the officers of the minaret, the heroes and heroines of the military service, the merits of their service to the people, their place in history have been forgotten. Thanks to independence, the ways of life and heroic deeds of historical figures along the Aral Sea region, 
studying the historically impartial, fair, objective assessment, demonstrating the lessons of the past as a historical lesson, new research is underway.

\section{REFERENCE}

1. Berdaq poems. Shejire. Tashkent, 1941.

2. Berdaq poems. Shejire. Nukus, 1950; 1993.

3. Xudaybergenov K. Family tree of Khiva khans. Xiva, 1996.

4. Munis and Ogahi. Firdavsi-il-iqbal. Tashkent, 2010.

5. Karakalpak translation by Academician H. Hamidi. Munis and Ogahi. Ferdausi-il-iqbol. Nukus, 2010.

6. Bazarbaev J.B., Bazarbaev R. A new look at history. Nukus, 2019.

7. Yusupov O.J. Russia and the peoples of the Aral Sea. Nukus, 1993.

8. Qunnazarov K. From the history of the construction of the Nukus fortress. Nukus, 2003.

9. Qunnazarov K. BES QALA. Country around the Sea. N.2010.

10. Taldaxmetov S.Sh. History of Kazakhstan. Almaty, 2013.

11. Embergenov U., Shamuratov J. Sulaymon Boqirgani (Hakim ota). Tashkent, 2015. 